\title{
Human wings apart-like gene is specifically overexpressed in cervical cancer
}

\author{
XIAOQIN LU ${ }^{1}$, JINQUAN CUI ${ }^{1}$, MEIZHOU FU ${ }^{2}$ and WULIANG WANG ${ }^{1}$ \\ ${ }^{1}$ Department of Obstetrics and Gynecology, The Second Affiliated Hospital of Zhengzhou University, Zhengzhou, \\ Henan 450014; ${ }^{2}$ Department of Intensive Care Unit, Henan Provincial People's Hospital, \\ Zhengzhou, Henan 450000, P.R. China
}

Received February 3, 2015; Accepted February 19, 2016

DOI: $10.3892 / \mathrm{ol} .2016 .4563$

\begin{abstract}
Cervical cancer is the third most commonly diagnosed cancer in women. The human wings apart-like (hWAPL) gene, which is 30,793 bp long and located on 10q23.2., is a human homologue of the WAPL gene in Drosophila melanogaster. hWAPL has the characteristics of an oncogene in uterine cervical cancer. The present study investigated the expression of the hWAPL gene in tissues, including 9 common cancers, consisting of cervical, gastric and lung cancers, liver, bladder, esophageal, endometrial, renal and rectal carcinomas, cervical intraepithelial neoplasia (CIN) and benign squamous epithelia. The immunohistochemical analysis was conducted using paraffin-embedded tissues obtained from 413 patients, consisting of 27 benign squamous epithelial tissue samples, and 47 cervical cancer, 30 cervical intraepithelial neoplasia (CIN)I, 33 CINII, 38 CINIII, 29 gastric cancer, 28 liver carcinoma, 26 bladder carcinoma, 35 esophageal carcinoma, 25 endometrial, 26 renal carcinoma, 36 rectal carcinoma and 33 lung cancer tissues. The expression of hWAPL mRNA was evaluated by reverse transcription-quantitative polymerase chain reaction in 8 benign squamous epithelia and 11 cervical cancer tissues. Compared to benign squamous epithelia and the 8 other cancers, hWAPL protein was significantly increased in cervical cancer $(\mathrm{P}<0.001)$. The expression of the hWAPL protein in cervical cancer and CINIII tissues was markedly increased compared to the expression in CINI and CINII tissues $(\mathrm{P}<0.001)$. Despite the significant difference in the staining scores $(\mathrm{P}<0.001)$, no significant difference was observed in the percentage of tissues expressing hWAPL $(\mathrm{P}=0.102)$ between cervical cancer and CINIII. The hWAPL gene may therefore be specifically overexpressed in cervical cancer. The overexpression of hWAPL may play an important role in occurrence and development of cervical cancer.
\end{abstract}

Correspondence to: Dr Jinquan Cui, Department of Obstetrics and Gynecology, The Second Affiliated Hospital of Zhengzhou University, 2 Jingba Road, Zhengzhou, Henan 450014, P.R. China E-mail: luxq1118@163.com

Key words: hWAPL, specific over-expressed gene, cervical cancer, CIN, cancer

\section{Introduction}

Cervical cancer is the third most commonly diagnosed cancer worldwide and the fourth leading cause of cancer-associated mortality in women, with 529,800 new cases and 275,100 mortalities among women in 2008 worldwide (1). The global incidence and mortality of cervical cancer have gradually decreased. In China, however, the incidence of cervical cancer remains high, particularly in young women (2). The widespread use of cervical screening programs and advances in various therapies, including surgery, chemotherapy, radiotherapy and combined therapy, have dramatically reduced the morbidity and mortality of cervical cancer. However, the number of newly diagnosed cases worldwide remains large, with 500,000 new cases each year (3). Despite the high prevalence, understanding of the molecular background in terms of genesis, growth and progress remain insufficient. Unfortunately, due to the lack of specific biomarkers, the gene diagnosis and biological treatment of cervical caner were restricted.

The wings apart-like (WAPL) gene of Drosophila melanogaster, which is located on X chromosome region 2D5-2D5, encodes a protein that regulates heterochromatin structure. Mutation of WAPL prevent the normal close apposition of sister chromatids in heterochromatin regions, but does not appear to affect either heterochromatin condensation or chromosomal segregation. This suggests that WAPL is required to hold sister chromatids together in mitotic heterochromatin. WAPL has also been implicated in heterochromatin pairing during female meiosis and the modulation of position effect variegation $(4,5)$. The hWAPL gene, which is $30,793 \mathrm{bp}$ long and located on 10q23.2., is a human homologue of the WAPL gene in Drosophila melanogaster. This gene encodes a cohesin-binding protein that facilitates the timely release of cohesin from chromosome arms during prophase. The mechanism of action of the hWAPL gene is not clear. However, overexpression of WAPL causes premature separation of sister chromatids (6). hWAPL has the characteristics of an oncogene and is associated with uterine cervical cancer (7).

The present study aimed to investigate the expression of the hWAPL gene in various tumor tissues. To identify the expression of hWAPL in various cancer tissues, 9 common cancers and CIN tissues were investigated, consisting of cervical, 
gastric and lung cancers, and liver, bladder, esophageal, endometrial, renal and rectal carcinoma. Furthermore, the expression of hWAPL messenger (m)RNA was investigated in benign squamous epithelia and cervical cancer tissues.

\section{Materials and methods}

Patients. The immunohistochemical analysis was conducted using paraffin-embedded tissues obtained from 413 patients, consisting of 27 benign squamous epithelia, 47 cervical cancer, 30 cervical intraepithelial neoplasia (CIN)I, 33 CINII, 38 CINIII, 29 gastric cancer, 28 liver carcinoma, 26 bladder carcinoma, 35 esophageal carcinoma, 25 endometrial carcinoma, 26 renal carcinoma, 36 rectal carcinoma and 33 lung cancer tissues. The selection criteria were as follows: i) Patients with no prior treatment; and ii) patients whose cancer is primary. In total, 8 benign squamous epithelia and 11 cervical cancer tissues were analyzed by reverse transcription-quantitative polymerase chain reaction (RT-qPCR) for the expression of hWAPL mRNA. All histopathological characteristics were confirmed by pathologists. Written informed consent was obtained from the patients for the publication of the present study. The study was approved by the Ethics Committee of the Second Affiliated Hosptial of Zhengzhou University (Zhengzhou, China).

Immunohistochemistry staining. Representative formalin fixed paraffin-embedded tissue blocks were selected and $5-\mu \mathrm{m}$ sections were cut, deparaffinized with xylene (Tianjin Rgent Chemical Co., Ltd., Tianjin, China) and rehydrated through graded alcohols (anhydrous alcohol, 95\% alcohol, 85\% alcohol, 75\% alcohol; (Tianjin Rgent Chemical Co., Ltd.). Antigen retrieval was performed by heating the slides in citrate buffer (1 mol/l; ZSGB-Bio, Bejing, China) at $98^{\circ} \mathrm{C}$ for $15 \mathrm{~min}$ in a water bath. Endogenous peroxidase was quenched for $10 \mathrm{~min}$ with peroxidase blocking reagent. Primary rabbit polyclonal anti-hWAPL antibody (catalog no., NBP1-92579; dilution, 1:200; Novus Biologicals Canada LLC, Oakville, ON, Canada) was incubated for $12 \mathrm{~h}$ at room temperature. Antibody staining was visualized using 2-step plus poly-HRP anti-mouse/rabbit IgG Detection System (catalog no., PV-9000; ZSGB-Bio). The sections were counterstained using Meyer's hematoxylin solution (ST Infinity HE Staining System; Leica Biosystems GmbH, Wetzlar, Germany). Negative controls (PBS instead of anti-hWAPL antibodies) were run simultaneously. The hWAPL protein expression was scored on the following scales, taking into account the intensity of staining and the proportion of cells stained in those cells. The staining intensity was classified as follows: 0 , No cells stained; 1 , weak staining; 2 , yellow cytoplasmic staining; and 3, deep brown cytoplasmic staining. The rate of cells expressing hWAPL was calculated as follows: Rate $(\%)=$ number of positive cells / total number of cells. The cells in 5 high-power fields were counted under a high-power lens (magnification, x400; BX43 Microscope; Olympus Corporation, Tokyo, Japan) and scored as follows: 0 , 0-5\% hWAPL-positive cells; $1,5-25 \%$ hWAPL-positive cells; 2, 26-50\% hWAPL-positive cells; 3, 51-75\% hWAPL-positive cells; and $4, \geq 76 \%$ hWAPL-positive cells. The product of the staining intensity and rate of cells expressing hWAPL was the final score. A score of $>3$ was considered positive. Two observers quantified the scores independently. The staining score was expressed as mean \pm standard deviation.

$R T-q P C R$ analysis. Total RNA was isolated from cervical squamous cell carcinoma tissues using the RNA Extraction kit (Beijing Dingguo Changsheng Biotechnology Co., Ltd., Beijing China). Complementary (c)DNA was synthesized in reaction mixture containing $3 \mu \mathrm{l}$ total RNA $(1 \mu \mathrm{g} / \mu \mathrm{l}), 1 \mu \mathrm{l}$ deoxynucleoside triphosphates (dNTPs; $10 \mathrm{mM}$ ), $0.5 \mu \mathrm{l}$ forward primer $(10 \mu \mathrm{M}), 0.5 \mu 1$ reverse primer $(10 \mu \mathrm{M}), 4 \mu \mathrm{l}$ 5X first strand buffer, $0.5 \mu 1$ RNase (40 U/ $\mu 1), 0.5 \mu 1$ Moloney murine leukemia virus reverse transcriptase $(200 \mathrm{U} / \mu \mathrm{l})$ and $10 \mu 1$ diethylpyrocarbonate (DEPC)-treated water. The reactions were incubated at $42^{\circ} \mathrm{C}$ for $1 \mathrm{~h}$, followed by $95^{\circ} \mathrm{C}$ for $10 \mathrm{~min}$ to terminate the reaction, and then quenched on ice for $5 \mathrm{~min}$. The hWAPL mRNA expression level was determined by RT-qPCR using an Applied Biosystems 7700 Sequence Detection System (Thermo Fisher Scientific, Inc., Waltham, MA, USA) and the following hWAPL primers: Forward, primer, 5'-AATTGTCGAGCACTGATAGAG-3'; and reverse, 5'-TTAAGTCAGCCTCAAGTACCC-3'. To normalize the amount of cDNA in each sample, the internal reference gene $\beta$-actin was quantified and used as the control for the experiment, with the following primers: Forward, 5'-ATCATGTTT GAGACCTTCAACA-3'; and reverse, 5'-CATCTCTTGCTC GAAGTCCA-3'. Each reaction contained $2 \mu \mathrm{cDNA}, 2.5 \mu \mathrm{l}$ 10X PCR buffer, $0.5 \mu 1 \mathrm{dNTPs}, 1 \mu \mathrm{l}$ SYBR green, $1.5 \mu \mathrm{l} \mathrm{\textrm {MgCl } _ { 2 }}$ $(25 \mathrm{mM}), 0.5 \mu \mathrm{l}$ forward primer, $0.5 \mu \mathrm{l}$ reverse primer, $0.5 \mu \mathrm{l}$ Cap Taq polymerase $(2 \mathrm{U} / \mu \mathrm{l})$ and DEPC-treated water was added to make a final volume of $25 \mu \mathrm{l}$. DNTPs, forward and revers primers, first strand buffer, RNase, Moloney murine leukemia virus reverse transcriptase and DEPC were all purchased from Beijing Dingguo Changsheng Biotechnology Co., Ltd. The reaction conditions were as follows: Initial denaturation for $2 \mathrm{~min}$ at $94^{\circ} \mathrm{C} ; 35$ cycles of denaturation for $30 \mathrm{sec}$ at $94^{\circ} \mathrm{C}$; renaturation for $30 \mathrm{sec}$ at $58^{\circ} \mathrm{C}$; and extension for $40 \mathrm{sec}$ at $72^{\circ} \mathrm{C}$. Following amplification, the critical cycle number (cycle threshold, Cq) (8), the amplification curve and the copy number of the target gene were provided by the PCR amplification instrument automatically. The relative quantification of hWAPL mRNA = copies of hWAPL mRNA / copies of reference $\beta$-actin. qPCR was repeated 3 times and the relative level of hWAPL mRNA was expressed as the mean \pm standard deviation.

Statistical analysis. Statistical analysis was performed using SPSS 10.0 software (SPSS, Inc., Chicago, IL, USA). The immunohistochemical staining score was analyzed using one-way analysis of variance. The percentage of tissues expressing hWAPL was analyzed using the $\chi^{2}$ test. The mRNA level of hWAPL in cervical carcinoma tissues and the normal tissues was analyzed by Student's $t$-test. $\mathrm{P}<0.05$ was considered to indicate a statistically significant difference. The confidence intervals were evaluated, with a 0.05 level of significance.

\section{Results}

Protein level of $h W A P L$ in cervical carcinoma, CIN and benign squamous epithelial tissues. The expression of hWAPL, which 


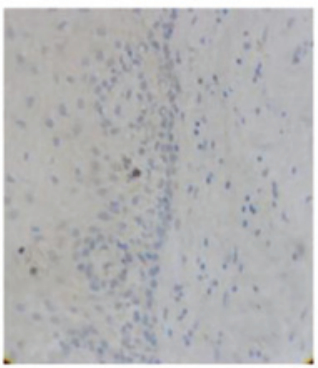

Bening squamous epithelia

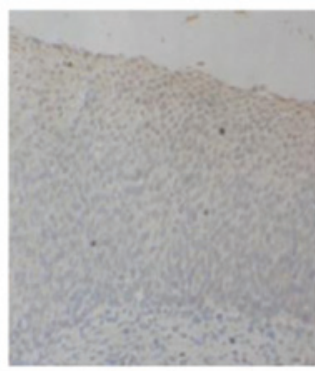

CINI

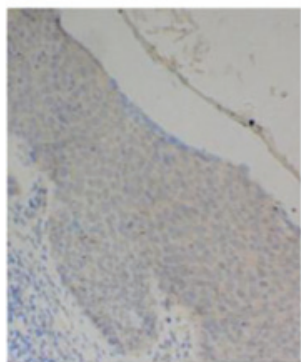

CINII

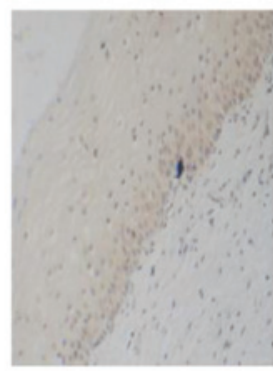

CINIII

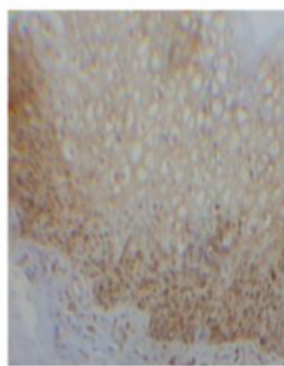

Cervical cance

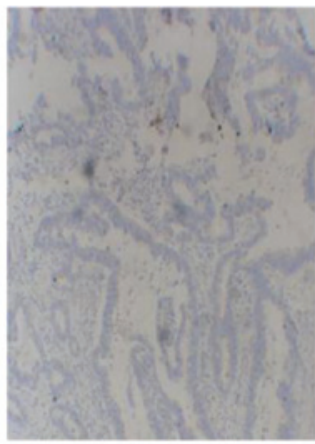

Gastric cancer

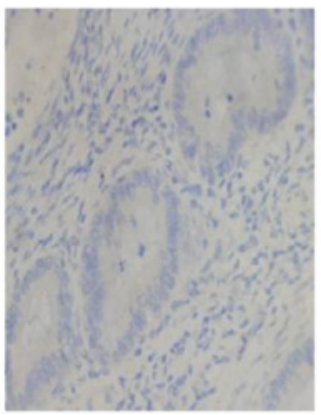

Carcinoma of the endometrium

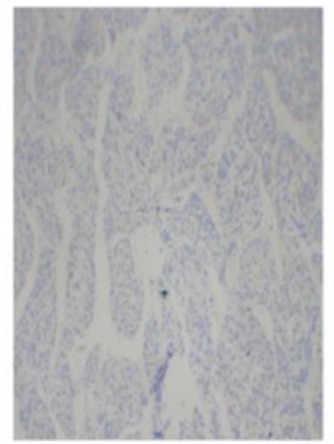

Carcinoma of the liver

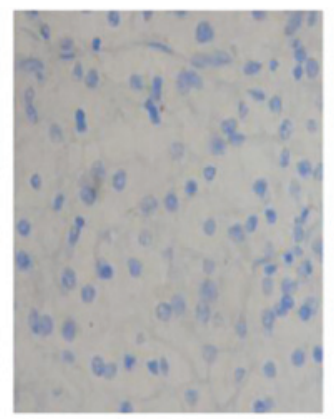

Renal carcinoma

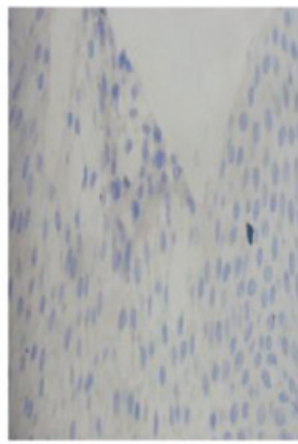

Bladder carcinoma

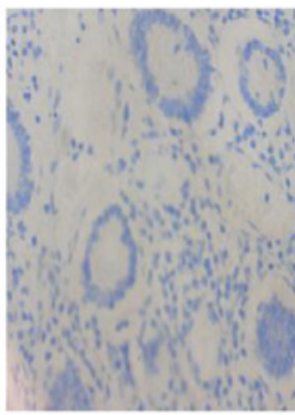

Carcinoma of the rectum

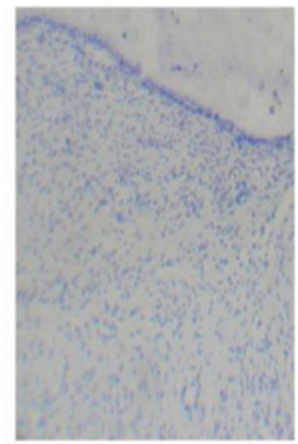

Carcinoma of the esophagus

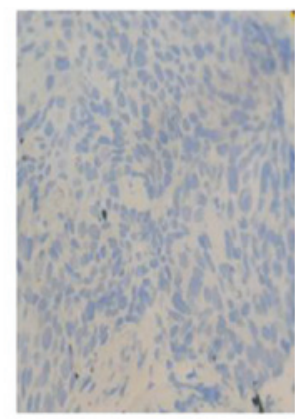

Lung cancer

Figure 1. Immunostaining for human wings apart-like messenger RNA in benign squamous epithelia tissues, CINI-III tissues and tissues from 9 types of cancer (magnification, x400). Benign squamous epithelia, hWAPL-negative expression 0.52 \pm 0.70 ; CINI, hWAPL-positive expression 2.20 \pm 1.19 ; CINII,

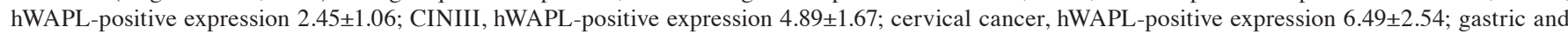
lung cancer, carcinoma of the liver, esophagus, endometrium and rectum and bladder and renal carcinoma, hWAPL-negative expression. Staining scores presented as the mean \pm standard deviation.

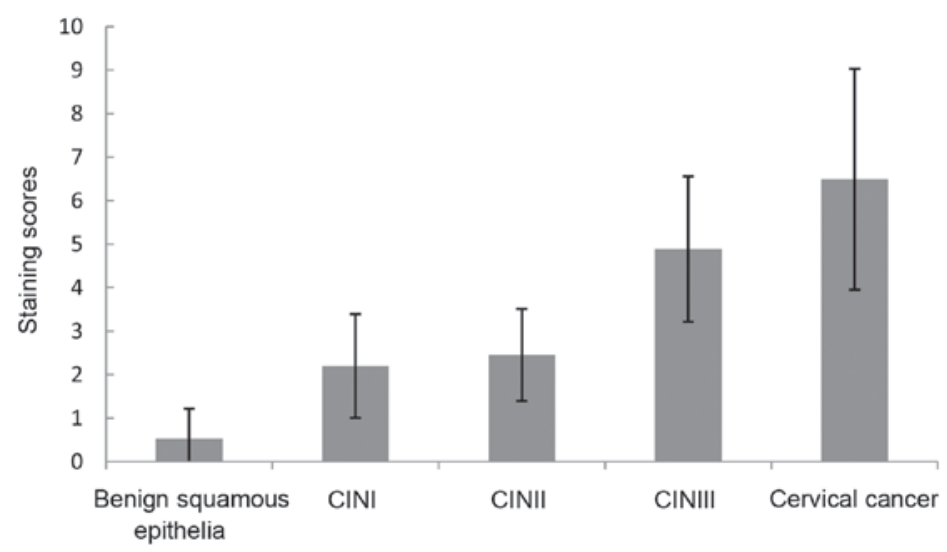

Figure 2. Staining scores of benign squamous epithelia, CINI, CINII, CINIII and cervical cancer tissues. The data are expressed as the mean \pm standard deviation. CIN, cervical intraepithelial neoplasia.

was located in the cytochylema and stained yellow or brown (Fig. 1), in terms of the staining scores and the percentage of tissues expressing hWAPL, were significantly increased in cervical squamous cell carcinoma (staining score, $6.49 \pm 2.54$; expression rate, $97.87 \%$ ), whereas no or weak staining was detected in benign squamous epithelial tissues (staining score, 
Table I. The staining scores of benign squamous epithelia, CINI, CINII, CINIII and cervical cancer.

\begin{tabular}{llcr}
\hline & \multicolumn{2}{c}{ Staining scores } \\
\cline { 2 - 4 } Tissue type & Range & Mean \pm standard deviation & F \\
\hline Benign squamous epithelia & $0.0-3.1$ & $0.52 \pm 0.70^{\mathrm{a}}$ & 70.26 \\
CINI & $1.2-4.3$ & $2.20 \pm 1.19^{\mathrm{b}}$ & $<0.001$ \\
CINII & $1.3-4.2$ & $2.45 \pm 1.06^{\mathrm{c}}$ & \\
CINIII & $2.5-8.1$ & $4.89 \pm 1.67^{\mathrm{d}}$ & \\
Cervical cancer & $2.6-12.3$ & $6.49 \pm 2.54^{\mathrm{e}}$ & \\
\hline
\end{tabular}

${ }^{a}$ Benign squamous epithelia vs. CINI, $\mathrm{P}<0.001$; ${ }^{\mathrm{b}} \mathrm{CINI}$ vs. $\mathrm{CINII}, \mathrm{P}=0.553$; ${ }^{\mathrm{c}} \mathrm{CINII}$ vs. CINIII, $\mathrm{P}<0.001$; ${ }^{\mathrm{d}} \mathrm{CINIII}$ vs. cervical cancer, $\mathrm{P}<0.001$; ebenign squamous epithelia vs. cervical cancer, $\mathrm{P}<0.001$. CIN, cervical intraepithelial neoplasia.

Table II. The rate of positive cell in benign squamous epithelia,CINI, CINII, CINIII and cervical cancer.

\begin{tabular}{lccc}
\hline Tissue type & Total, $\mathrm{n}$ & $\begin{array}{c}\text { Tissues expressing } \\
\text { hWAPL, } \mathrm{n}(\%)\end{array}$ & $\chi^{2}$ \\
\hline Benign squamous epithelia & 27 & $1(3.70)^{\mathrm{a}}$ & 87.531 \\
CINI & 30 & $12(40.0)^{\mathrm{b}}$ & $<0.001$ \\
CINII & 33 & $34(42.4)^{\mathrm{c}}$ & $46.5)^{\mathrm{d}}$ \\
CINIII & 38 & $46(97.9)^{\mathrm{e}}$ & \\
Cervical cancer & 47 & & \\
\hline
\end{tabular}

${ }^{a}$ Benign squamous epithelia vs. CINI, $\chi^{2}=10.634$ and $\mathrm{P}=0.001$; ${ }^{\mathrm{b}} \mathrm{CINI}$ vs. CINII, $\chi^{2}=0.038$ and $\mathrm{P}=0.845$; ${ }^{\mathrm{c}} \mathrm{CINII}$ vs. CINIII, $\chi^{2}=17.852$ and $\mathrm{P}<0.001$; ${ }^{\mathrm{d} C I N I I I}$ vs. cervical cancer, $\chi^{2}=2.677$ and $\mathrm{P}=0.102$; ${ }^{\mathrm{e}}$ cervical cancer vs. benign squamous epithelia, $\chi^{2}=65.621$ and $\mathrm{P}=0.001$. $\mathrm{hWAPL}$, human wings apart-like; CIN, cervical intraepithelial neoplasia.

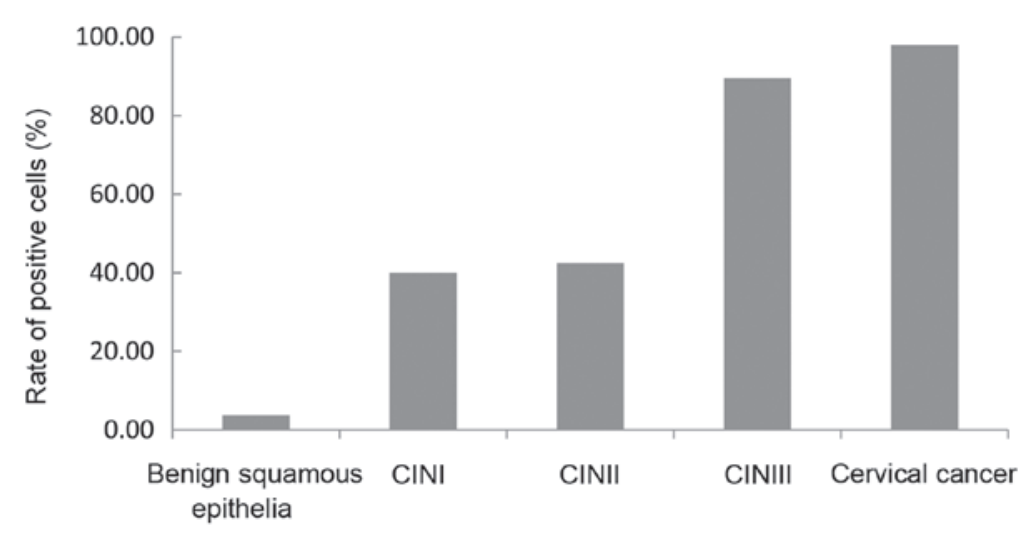

Figure 3. Percentage of tissue samples expressing hWAPL in benign squamous epithelia, CINI, CINII, CINIII and cervical cancer. CIN, cervical intraepithelial neoplasia. hWAPL, human wings apart-like.

$0.52 \pm 0.70$; expression rate, $3.70 \%$ ). The staining scores and the percentage of tissues expressing hWAPL increased gradually with the development of CIN between CINI (staining score, $2.20 \pm 1.19$; expression rate, $40.00 \%$ ), CINII (staining score, 2.45 \pm 1.06 ; expression rate, $89.47 \%$ ) and CINIII (staining score, $4.89 \pm 1.67$; expression rate, $42.42 \%$ ). The staining scores and the percentage of tissues expressing hWAPL in cervical cancer and CINIII were significantly increased compared with CINI and CINII tissues ( $\mathrm{P}<0.001$; Tables I and II; Figs. 2 and 3). Despite the difference in the staining scores $(\mathrm{P}<0.001)$, no significant difference was observed in the percentage of tissues expressing hWAPL $(\mathrm{P}=0.102)$ between cervical cancer and CINIII. Furthermore, the differences between the staining scores and percentage of tissues expressing hWAPL in CINI and CINII were not significant. The development of the cervical lesion was therefore associated with an increased expression of hWAPL.

Protein level of hWAPL in other cancer tissues. The expression of hWAPL was not present in gastric cancer, liver, 
Table III. Expression of hWAPL mRNA in benign squamous epithelia and cervical cancer.

\begin{tabular}{lccr}
\hline Tissue type & Total, $\mathrm{n}$ & hWAPL mRNA level & $t$ \\
\hline Benign squamous epithelia & 8 & $1.81 \pm 0.58$ & P-value \\
Cervical cancer & 11 & $11.16 \pm 1.097$ & 21.838 \\
\hline
\end{tabular}

Data are expressed as the mean \pm standard deviation. hWAPL, human wings apart-like; mRNA, messenger RNA.

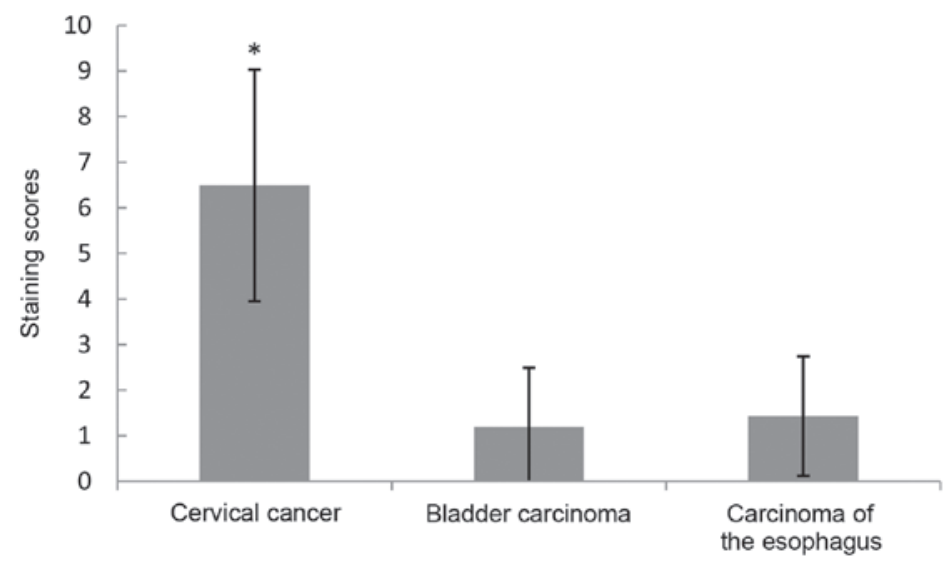

Figure 4. Staining scores for cervical cancer, bladder carcinoma and carcinoma of the esophagus. The staining scores for hWAPL in cervical cancer (6.49 \pm 2.54$)$ were significantly increased compared with the scores for bladder carcinoma $(1.19 \pm 1.03)$ and carcinoma of the esopgagus $(1.43 \pm 1.31)$. The expression of hWAPL was absent in the other 6 types of cancer. The data are expressed as the mean \pm standard deviation. ${ }^{*} \mathrm{P}<0.001$. hWAPL, human wings apart-like.

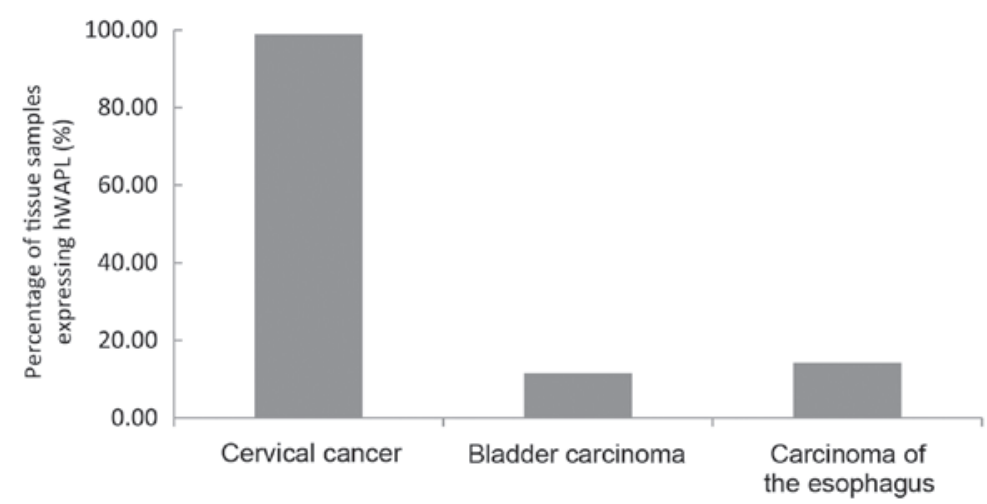

Figure 5. Percentage of tissue samples expressing hWAPL in cervical cancer, bladder carcinoma and carcinoma of the esophagus. The percentage of tissue samples expressing hWAPL in cervical cancer (97.9\%) was significantly increasaed compared with the percentage of bladder carcinoma tissues (11.54\%) and carcinoma of the esopgagus tissues (14.28\%). The expression of hWAPL was absent in the other 6 types of cancer. hWAPL, human wings apart-like.

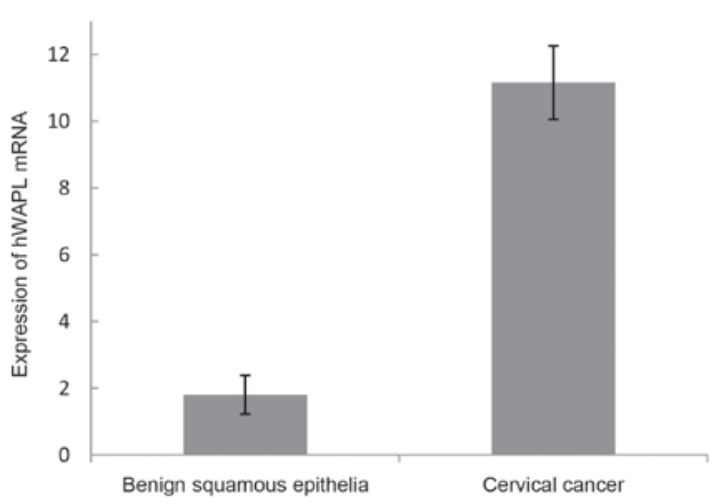

Figure 6. Expression of hWAPL mRNA in benign squamous epithelia and cervical cancer. hWAPL, human wings apart-like; mRNA, messenger RNA. endometrial, renal or rectal carcinoma, or lung cancer. In contrast to the staining scores and the percentage of tissues expressing hWAPL in bladder carcinoma (staining score, $1.19 \pm 1.03$; expression rate, $11.54 \%$ ) and esophageal carcinoma (staining score, $1.43 \pm 1.31$; expression rate, $14.28 \%$ ), the staining scores and the percentage of tissues expressing hWAPL were significantly increased in cervical cancer $(\mathrm{P}<0.001$; Figs. 4 and 5). The hWAPL gene was overexpressed only in cervical cancer.

hWAPL mRNA level in cervical carcinoma and normal cervical tissues. In total, 10 cervical carcinoma tissues and 7 normal cervical tissues were examined for hWAPL gene expression by RT-qPCR. The mean hWAPL mRNA level was 
$11.16 \pm 1.20$ in cervical cancer tissues and $1.81 \pm 0.58$ in normal cervical tissues (Table III; Fig. 6). The difference between cervical tissues and normal cervical tissues was significant $(t=21.838 ; \mathrm{P}<0.01)$. Thus, the expression of the hWAPL gene was significantly increased in cervical carcinoma tissues.

\section{Discussion}

The most important finding of the present study was that the expression level of the hWAPL gene was significantly increased in cervical cancer tissues compared with the 8 other common cancers analyzed. Findings of previous study have suggested that the hWAPL gene is specifically overexpressed in cervical cancer (7). It is well known that a pathological cervical lesion develops through step-by-step events, progressing between normal benign squamous epithelia, cervical intraepithelial neoplasia and cervical cancer. The present study demonstrated that the staining scores and the percentage of tissues expressing hWAPL increased gradually between normal benign squamous epithelia, CINI, CINII, CINIII and cervical cancer. In normal benign squamous epithelia, there was no expression of hWAPL or the expression was limited to the basement membrane of the epithelium. In addition, the expression of hWAPL was located in the bottom of the epithelium. Notably, the expression of hWAPL was positive in the total layer of epithelium in CINIII and cervical cancer. These results indicated that the overexpression of hWAPL may play an important role in the occurrence and development of cervical cancer. This is in accordance with the analyses performed by Oikawa et al (7).

Currently, the cause of hWAPL specific-overexpression is not clear in cervical cancer. To the best of our knowledge, it is well understood that, as a dominant reason, HPV play a canonical role in occurrence and development of cervical cancer $(9,10)$. The expression of HPV E6 and E7 oncogenes is responsible for cervical neoplasia (11). An association has been revealed between hWAPL overexpression and HPV infection in a previous study (12). hWAPL expression was increased by HPV E6 and E7 oncoproteins (12). In the present study, expression of hWAPL, which was observed in certain esophageal carcinoma tissues, may be due to HPV infection. The pathway of hWAPL overexpression and the association between hWAPL over-expression and HPV infection require additional elucidation.

In conclusion, the hWAPL gene may be specifically overexpressed in cervical cancer. The expression of hWAPL is associated with the grade of the cervix lesion, and the hWAPL gene may be a novel target for the diagnosis and therapy of cervical cancer.

\section{Acknowledgements}

This work was supported by the Natural Science Foundation of the Education Department of Henan Province, China (grant no. 2006320012).

\section{References}

1. Jemal A, Bray F, Center MM, Ferlay J, Ward E and Forman D: Global cancer statistics. CA Cancer J Clin 61: 69-90, 2011.

2. Pan Z, Li J, Pan X, Chen S, Wang Z, Li F, Qu S and Shao R: Methylation of the RASSF1A gene promoter in Uigur women with cervical squamous cell carcinoma. Tumori 95: 76-80, 2009.

3. Dueñas-González A, Lizano M, Candelaria M, Cetina L, Arce C and Cervera E: Epigenetics of cervical cancer. An overview and therapeutic perspectives. Mol Cancer 4: 38, 2005.

4. Verní F, Gandhi R, Goldberg ML and Gatti M: Genetic and molecular analysis of wings apart-like (WAPL), a gene controlling heterochromatin organization in drosophila melanogaster. Genetics 154: 1693-1710, 2000

5. Dobie KW, Kennedy CD, Velasco VM, McGrath TL, Weko J, Patterson RW and Karpen GH: Identification of chromosome inheritance modifiers in drosophila melanogaster. Genetics 157: 1623-1637, 2001.

6. Gandhi R, Gillespie PJ and Hirano T: Human Wapl is a cohesin-binding protein that promotes sister-chromatid resolution in mitotic prophase. Curr Biol 16: 2406-2417, 2006.

7. Oikawa K, Ohbayashi T, Kiyono T, Nishi H, Isaka K, Umezawa A, Kuroda M and Mukai K: Expression of a novel human gene, human wings apart-like (hWAPL), is associated with cervical carcinogenesis an tumor progression. Cancer Res 64: 3545-3549, 2004.

8. Livak KJ and Schmittgen TD: Analysis of relative gene expression data using real-time quantitative PCR and the 2(-Delta Delta C(T)) Method. Methods 25: 402-408, 2001.

9. Adersson S, Rylander E, Larsson B, Strand A, Silfversvärd C and Wilander E: The role of human papillomavirus in cervical adenocarcinoma carcinogenesis. Eur J Cancer 37: 246-250, 2001.

10. Muñoz N, Bosch FX, de Sanjosé S, Herrero R, Castellsagué X, Shah KV, Snijders PJ and Meijer CJ; International Agency for Research on Cancer Multicenter Cervical Cancer Study Group: Epidemiologic classification of human papillomavirus types associated with cervical caner. N Engl J Med 348: 518-527, 2003.

11. Doorbar J, Quint W, Banks L, Bravo IG, Stoler M, Broker TR and Stanley MA: The biology and life-cycle of human papillomaviruses. Vaccine 30 (Suppl 5): F55-F70, 2012.

12. Kuroda M, Kiyono T, Oikawa K, Yoshida K and Mukai K: The human papillomavirus E6 and E7 inducible oncogene, hWAPL, exhibits potential as a therapeutic target. Br J Cancer 92: 290-293, 2005. 